\title{
Financialization of commodities
}

\author{
Michał Falkowski
}

ABSTRACT

\begin{abstract}
The basic theory of price formation tells us how the price of a particular asset will change based on the adjustment to its supply and demand. However, values of assets are also determined by other business fundamentals, company's and world events, human psychology, and investors' belief about the possible future profit. In recent history that lead to an increase of individual and institutional investors' interest in allocating their resources in commodity markets. With a large inflow of capital commodities' prices started to rise making them attractive components to effective investment portfolios.

The presented paper addresses the issue of so called commodities'financialization' process. It looks at the main factors standing behind commodities' price movements and to what extent financial market participants contributed to commodities price volatility in recent years. Based on the data examined it distinguishes the involvement of both commercial and non-commercial traders in short and long term periods of time. As well as explaining the impact of growing investors' interest in commodity markets it defines other market forces - like currency appreciations and emerging markets - as being part of increased volatility in raw and soft commodity markets. Along with market examination the paper focuses on possible future outcomes in attempts to regulate commodities derivatives markets and potential effects of those efforts.
\end{abstract}

KEY WORDS: $\quad$ commodities, financial markets, futures, index funds, market speculation,

JEL Classification: G00

'Excelian Limited, United Kingdom

\section{Introduction}

Since early 2000s, commodity futures have emerged as a popular asset class for many financial institutions. According to a CFTC staff report (Commodity Futures Trading Commission, 2008), the total value of various commodity index-related instruments purchased by institutional investors had increased from an estimated \$15 billion in 2003 to at least $\$ 200$ billion in mid-2008. Various observers and policy makers have expressed a strong concern that index investment as form of financial speculation might have caused unwarranted increases in the cost of energy and food

-

Corespondence concerning to this article should be addressed to: mfalkowski@poczta.onet.pl and induced excessive price volatility (Barone, 2008). It was commonly asserted that speculative buying by financial players in commodity futures and over-thecounter (OTC) derivatives markets created a "commodity bubble", with the result that commodity prices far exceeded fundamental values at the peak (Masters, White, 2008). The argument of an increasing bubble was mostly justified with a large amount of money invested in different types of commodity derivatives over the last few years and that this gigantic wave of money resulted in significant and unwarranted upward pressure on commodity prices. To address the question of impact of the rapid growth of commodity index investment, it is important to recognize the concurrent economic transition of commodities markets precipitated by the rapid growth of commodity index investment. 


\section{Definition of financialization}

To understand the process of commodity markets financialization it is important to recognize the term of financialization itself. In general financialization may be defined as the increasing dominance of the finance industry in the sum total of economic activity, of financial controllers in the management of corporations, of financial assets among total assets, of marketised securities and particularly equities among financial assets, of the stock market as a market for corporate control in determining corporate strategies, and of fluctuations in the stock market as a determinant of business cycles (Dore, 2000). However, more popularly, financialization is understood to mean the vastly expanded role of financial motives, financial markets, financial actors and financial institutions in the operation of domestic and international economies, and in this case, the increasing role in commodities markets (Casey, 2011).

In the past there was a general view that commodities markets were largely or at least partially segmented from financial markets by having little price co-movements with stocks (Gorton, Rouwenhorst, 2006) and with each other in different sectors (Erb, Campbell, 2006). It has been also discussed that commodity prices provided investors with risk premium for commodity price risk (de Roon, Nijman, Veld, 2000). The trend changed in early 2000s, as the below chart 1 shows, with a large inflow of assets into commodity market in quite a marked way, rather than a smooth process of covering it. Two investment indexes, Standard\&Poors Goldman Sachs Commodity Index (SP-GSCI) and Dow Jones- American International Group Commodity Index (DJ-AIG) clearly show how fast commodity markets attracted new capital and in a result how the spot price of various commodities represented by Standard\&Poors' GSCI Spot Price Index reacted to that new trend.

Some argue that this 'step change' resulted from the equity market collapse at that time, and that as a result helped investors discover a small negative correlation between commodity returns and stock returns and build a belief that commodity derivatives could be used to reduce portfolio risk (Gorton, Rouwenhorst, 2006).

Figure 1. Commodity Index Allocations versus S\&P GSCI Spot Price Index

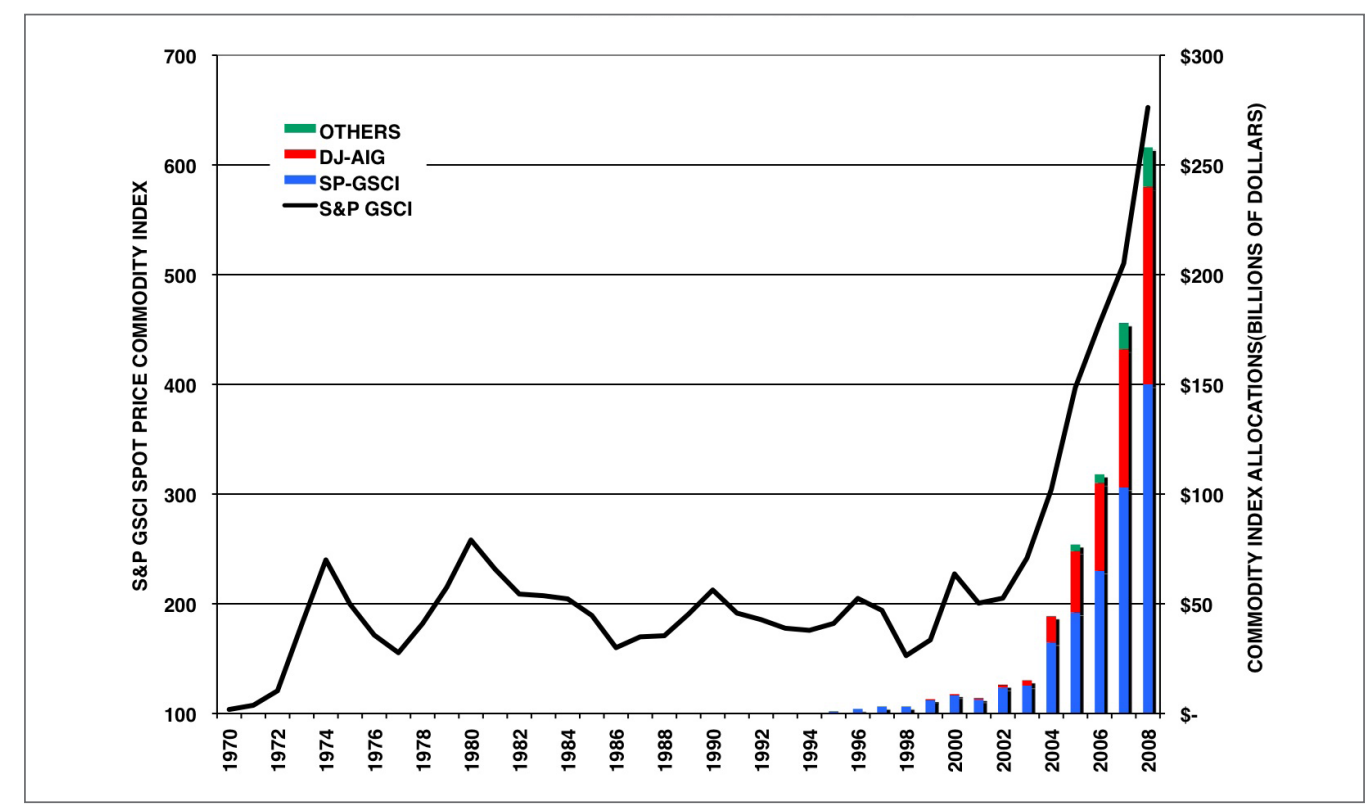

Source: Goldman Sachs, Dow Jones, Bloomberg and estimates derived from CFTC CIT Supplement 2008 data point represents data through March 12 
With that information investment banks and other financial institutions were able to successfully promote commodity derivatives as a new class of prudent investments.

As a result, various instruments based on commodity indices have attracted billions of dollars of investment from institutional investors and individuals (Hughes, 2006). The increasing presence of investors allocating money in commodities derivatives initiated the so called process of 'financialization' amongst commodities markets, which many argue made commodity prices more correlated with prices of financial assets and with each other.

The increasing presence of index investors made commodity prices more volatile but secondly investors' deci- sions and portfolio rebalancing could also act as a channel to spill over shocks from outside to commodities markets and across different sectors (Kyle, Xiong, 2001). By looking at the below chart 2 it is hard not to conclude that financial demand for profit, which was followed by huge inflows of cash to commodity trading mechanisms has at least played some role in the run-up of, for example, oil prices in recent years. Below it's possible to notice how the price of barrel of oil, in this case represented by West Texas Intermediate (WTI) Crude Oil price followed the inflow of capital to two previously mentioned index investment mechanisms (Standard\&Poors Goldman Sachs Commodity Index and Dow Jones-AIG).

Figure 2. Passive Commodity Index Investments vs. Crude Oil (USD billion)

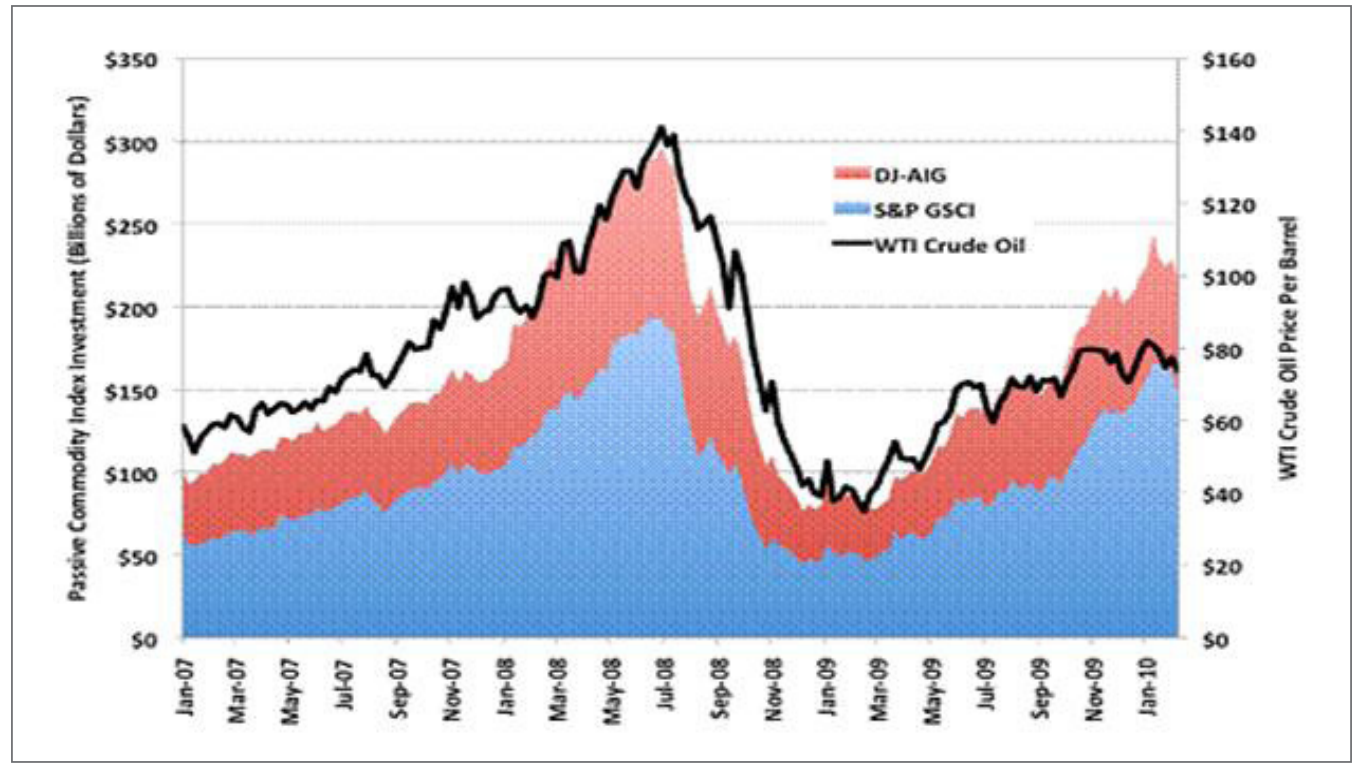

Another thing that is worth mentioning is that the increase in trading in commodity derivatives over the past decade far outstripped the growth in commodity production and the need of derivatives to hedge risk by commercial producers and users of commodities (Knoepfel, 2011). Chart number 3 illustrates the ratio between physical and financial futures contracts (New York Mercantile Exchange WTI Futures, Intercontinental Exchange (ICE) WTI Futures and Brent Oil Futures) in the crude oil markets. Over the past 15 years, financial futures have grown from 2 times the size of physical markets to almost 12 times the size.

As a consequence of a general market trend many institutional portfolio managers added commodities derivatives as an asset class to their portfolios. This addition was part of a larger shift in portfolio's strategy building mentioned above. Trading in commodity derivatives also increased along with the rapid expansion of trading in all derivatives markets which became more popular with the development of financial markets (Kevin, 2011). 
Figure 3. Financial vs. Physical markets

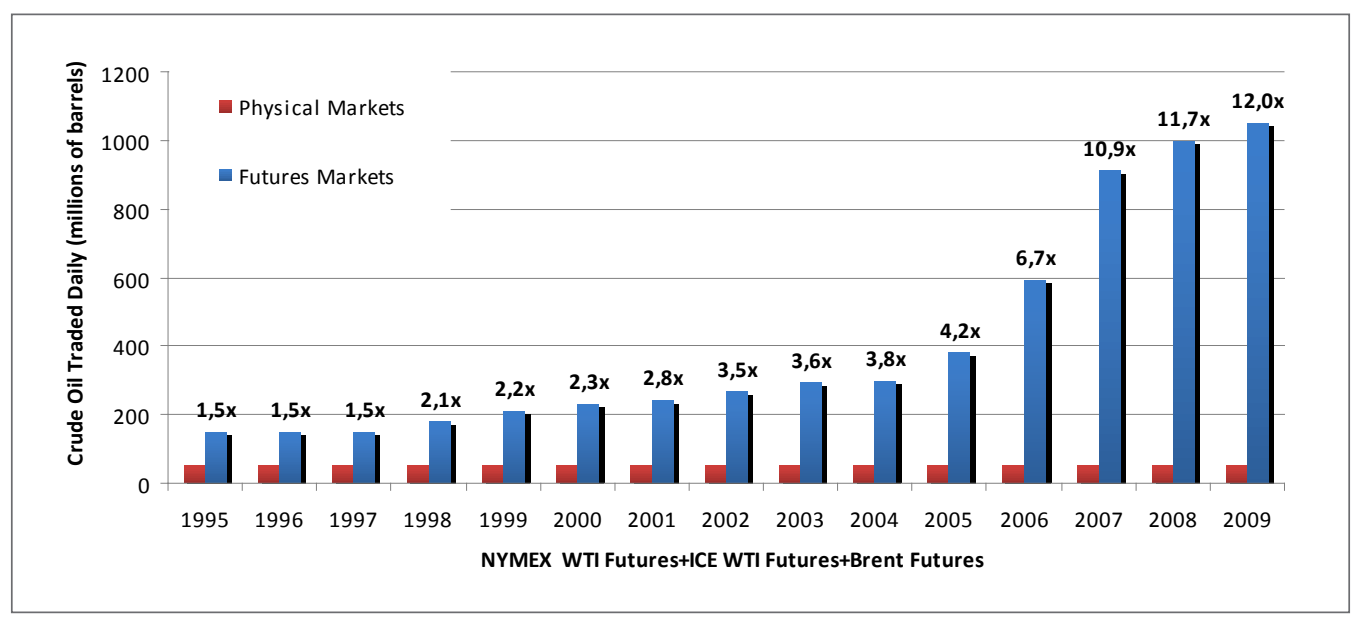

Source: Based on data from Masters Capital Management

\section{Changing structure of commodity markets by different types of partici- pants}

There are few other factors which play a role in determining the increase of interest in commodities and commodity derivatives, and explain the interest of different types of financial actors. One explanation for the rise in their trading is that there was a general boost in search of risky investments which was attributed to the search for higher yield in a low interest rate environment. Second could be the non-commercial investors' usage of commodity derivatives to hedge against equity risk and also commercial market participants' use of derivatives to hedge against price fluctuations - when they want to secure the price of oil or any other commodity they plan to extract or purchase in the future (Alexander, Barbosa, 2007). We can not also forget about the increasing involvement of noise traders in the commodity markets and investors that generally have poor timing, follow trends, and over-react to good and bad news, hence fill the market with "speculative" money.

Market participants involved in commodity and commodity derivatives trading broadly fit into two categories: commercial and non-commercial (U.S. Commodity Futures Trading Commission, 2011). As already mentioned above commercial participants are those who are physically involved with the production and consumption of commodities. They use derivatives markets to hedge against price fluctuations.
Non-commercial participants on other hand want to improve or diversify their portfolios and do not want to take physical delivery of oil or any other commodity. Within this group there are active investors (often referred to speculators) and index funds (Dunsby, Eckstein, Gaspar, 2008).

Although, the term speculator is often misused active market participants are characterised as investors who allocate their capital actively and who use their 'better information' to try to make profit by anticipating movements in commodity prices. They often take investment decisions, establishing long as well as short positions, based on the hope and expectation there will be a profit, but no firm evidence that this will be the case.

Separately from active long-short investors, index funds use only long-passive strategies. Commodity index funds have a mandate to track a set basket of commodities and in contrast to active investors' searching for profit, they are looking to diversify their portfolios. Considering the non-physical interest of their trading, the structure of index funds has lead to allegations that they are unwarrantedly driving demand for oil by rolling over the expiring contacts for commodities. However, the European Central Bank undermined that thesis noting that it is unlikely, as index funds do not take physical delivery of a commodity, and furthermore are of a small size relative to the size of the physical market where the spot price is largely decided (European Central Bank, 2008). 


\section{What formulates the commodity prices?}

There are many factors that impact the movement of commodities prices for example weather conditions, amount of acres planted, production strikes, crop diseases, technological developments or international trade unions. Commodities are also capital intensive products to produce, have considerable lead times and in many cases are politically controlled, through subsidies, taxes or trade restrictions. All of these are important and have considerable influence on cost of production, export potential and therefore prices.

Some argue that, one of the results of the financialization process is that prices of individual commodities moved away from supply and demand fundamentals. Commodity prices are also being determined by a whole set of financial factors, such as the aggregation of risk appetite for financial assets and investment behaviour of diversified commodity index investors. On one hand, the presence of these investors can lead to more efficient sharing of commodity price risk as well as improve liquidity for this particular market, on the other, some argue their involvement can potentially result in increased volatility across different commodity classes.

Physical commodity prices are influenced by supply and demand, which are often referred as fundamental factors. Unlike financial assets, the value of commodities is also affected by attributes such as physical quality and location (Trostle, 2008).

Commodity supply is a function of production. Supply may be reduced if problems with production or delivery occur, such as crop failures or labour disputes. In some commodities, seasonal variations of supply and demand are usual and shortages are not uncommon.

On the other hand demand for commodities may be affected if final consumers are able to obtain substitutes at a lower cost. There may also be major shifts in consumer taste over the long term if there are supplies or cost issues. Commodity traders are sensitive to the tendency of certain commodity prices to vary according to the stage of the economic cycle.

Commodity prices may also be affected by a number of additional factors, including:

- Expected levels of inflation (particularly for precious metals),

- Interest rates,

- Exchange rates,
- General economic conditions,

- Costs of production and ability to deliver to buyers,

- Availability of substitutes and shifts in taste and consumption,

- Weather, particularly for agricultural commodities and energy,

- Political stability, particularly for energy and precious metals (Horcher, 2005).

Commodity price movements are also closely tied to inventory and storage capacity. Inventories firstly serve as a bridge between physical supply of a commodity and the current global market demand. An inability to manage either of these through supply and demand shocks, such as drought or production strikes can force prices to react quickly and aggressively. There are large, expensive infrastructure constraints to storage of commodities, in fact if there was an infinite ability to store excess supply there would be very little fluctuation in price of many commodities in the short term. The easier a commodity is to store the less volatile the price will most likely be. Agricultural commodities can have the additional constraint of being perishable, adding a further constraint of time they can be stored. When a commodity has low inventories then consumers are more likely to pay a premium for the scarcer commodity.

\section{The role of speculation in the com- modities market}

All of the abovementioned factors refer to fundamental aspects standing behind commodities price movements. Regarding the volatility in the hard commodity prices as well as recent increase of food prices that overtook the early 2008 peak (Mittal, 2009) many blame yet another factor - speculation (Gilbert, 2009). It is true that increased inflow of capital to index funds and a broader investors' interest in commodities trading, as chart 4 shows, might made prices more volatile in short term, though the evidence that it can make prices surge in a longer period is weak.

It is worth noticing that simple trading of commodities as one of many asset classes cannot singly drive prices up in the long term because behind each buy there is a sell (The Economist Magazine, 2011) where the forces of supply and demand from both sides of the market would eventually move commodity prices closer to their fundamental levels. 
Figure 4. EU and Asian commodity investments and CRX' index value from 2000 to 2010
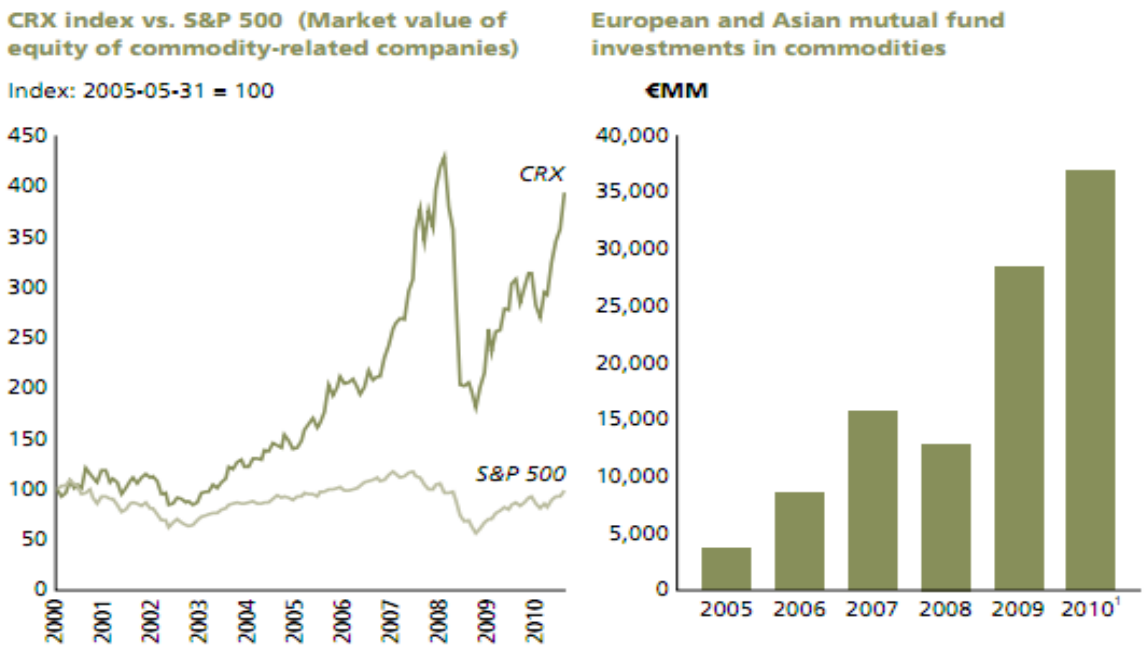

Source: Bloomberg

In this regard we could quote Tom Hieronymus who said that for every long there is a short, for everyone who thinks the price is going up there is someone who thinks it is going down, and for everyone who trades with the flow of the market, there is someone trading against it (Hieronymus, 1977).

Considering the potential impact of financial market participant on commodity prices one question remains - to what extent financial markets can affect prices of different types of commodities? One argument supporting the thesis of minor reactions can be seen on both chart 5 and chart 6 , where we can notice implications that there might not be a positive correlation between non-commercial investors' capital flowing to commodity markets as a whole and their prices.

The first chart shows the reaction of the DJ-UBSCI Energy Sub-Index ${ }^{2}$, to investors' activities in the energy commodities market. The interesting point worth making is that from the peak year of 2008 the future prices contracts of energy commodities did not show a clear correlation with investors' activities in that sector. From the middle of 2008 the index showed a decreasing trend, while investors' concentration in that period increased with a visible periods of strong volatility.

The second chart shows a similar situation with the behaviour of the CRB index ${ }^{3}$, representing a broader spectrum of commodities, compared with ratio of speculators' open interest. What is worth noticing is the fact that during the analysed period the index replicating the behaviour of commodity prices reflected the similar trend as investors' open interest, however the sharp changes in their investment strategies were not reflected in an increased fluctuation of commodities prices. That in fact could in some wayindicate that long term commodities prices are not that closely influenced by financial market participants and their involvement in those asset classes.

Criticism of derivatives markets and the people who operate in them stems from the belief that non-commercial participants do not stabilise prices by bringing new information to the market, but that they destabilise it by driving prices away from their fundamentals. However, apart from the affirmation that speculative investments were responsible for the rapid growth of commodity prices there can be also some implications indicating that there are ways in which the presence of financial investors could in fact stabilize the market. For instance:

- when a passive long-only investor enters the market, establishes its positions and will now follow a strategy of keeping a balanced portfolio of different asset classes, then it will now tend to be a systematic seller of the market when it rises and a buyer 
Figure 5. Energy market speculation vs. prices

Speculators' share of US oil, gasoline, heating oil and natural gas markets at record.

$15-$ Ratio of speculators to open interest $\quad-$ DJ-UBS energy sub-index ${ }_{500}$

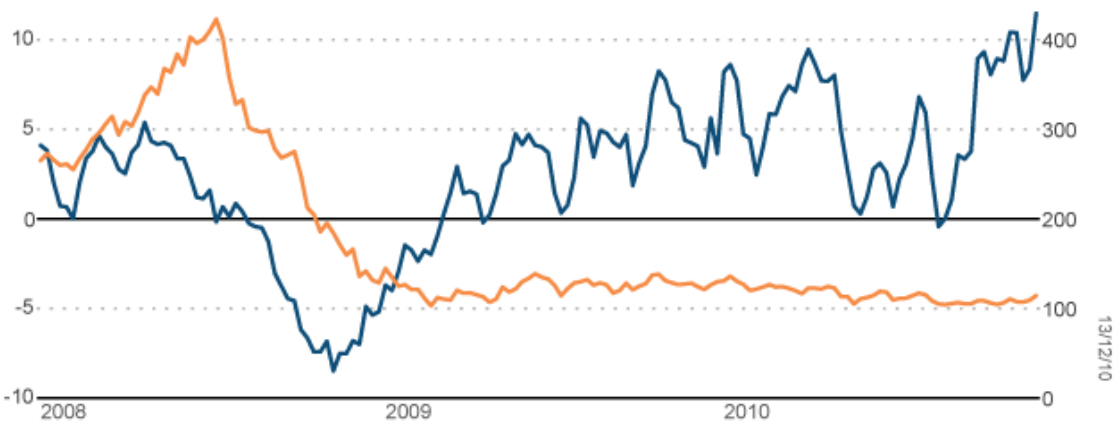

Source: Reuters graphic/Stephen Culp

Figure 5. Commodities market speculation vs. prices

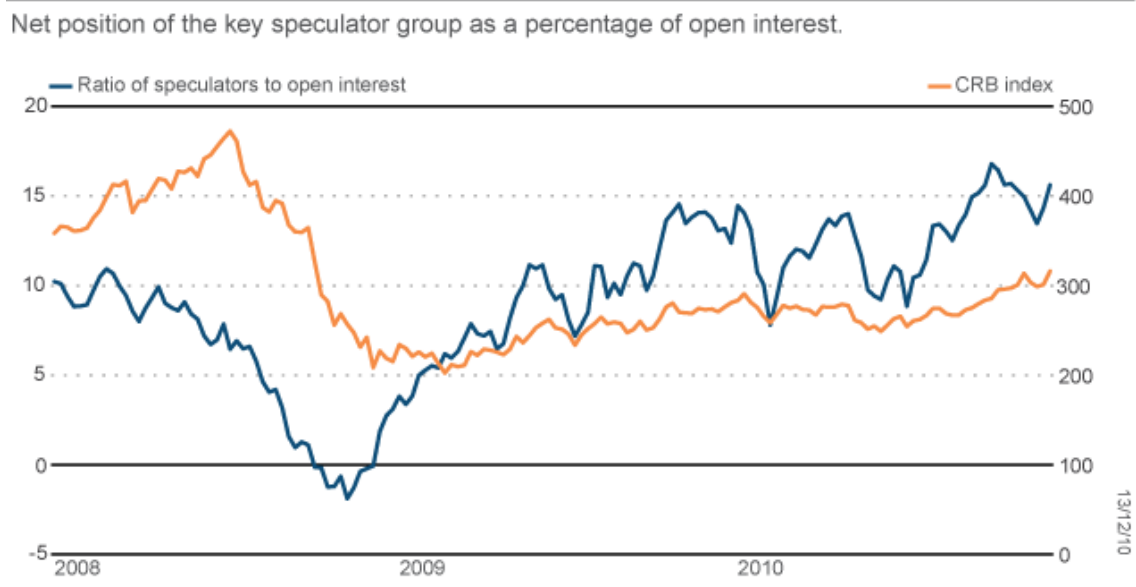

Source: Reuters graphic/Stephen Culp

when it falls, playing therefore a stabilizing antimomentum role (Garman, Forgue, 2010);

- considering the market activity of the long-short active investors who truly do analyse the fundamentals of supply and demand carefully, and do so more effectively than the commercial players (producers and consumers), then their activity can help make the market more efficient by, for example, driving future prices (and, as a result the spot price) higher in anticipation of a future tightness of supply and demand, potentially reducing the extreme volatility which could result from more sudden realization of supply/demand imbalances (Turner, Justham, Farrimond, Hill, 2011); 

Figure 7. OTC commodity contacts (bln \$) vs. commodity price index

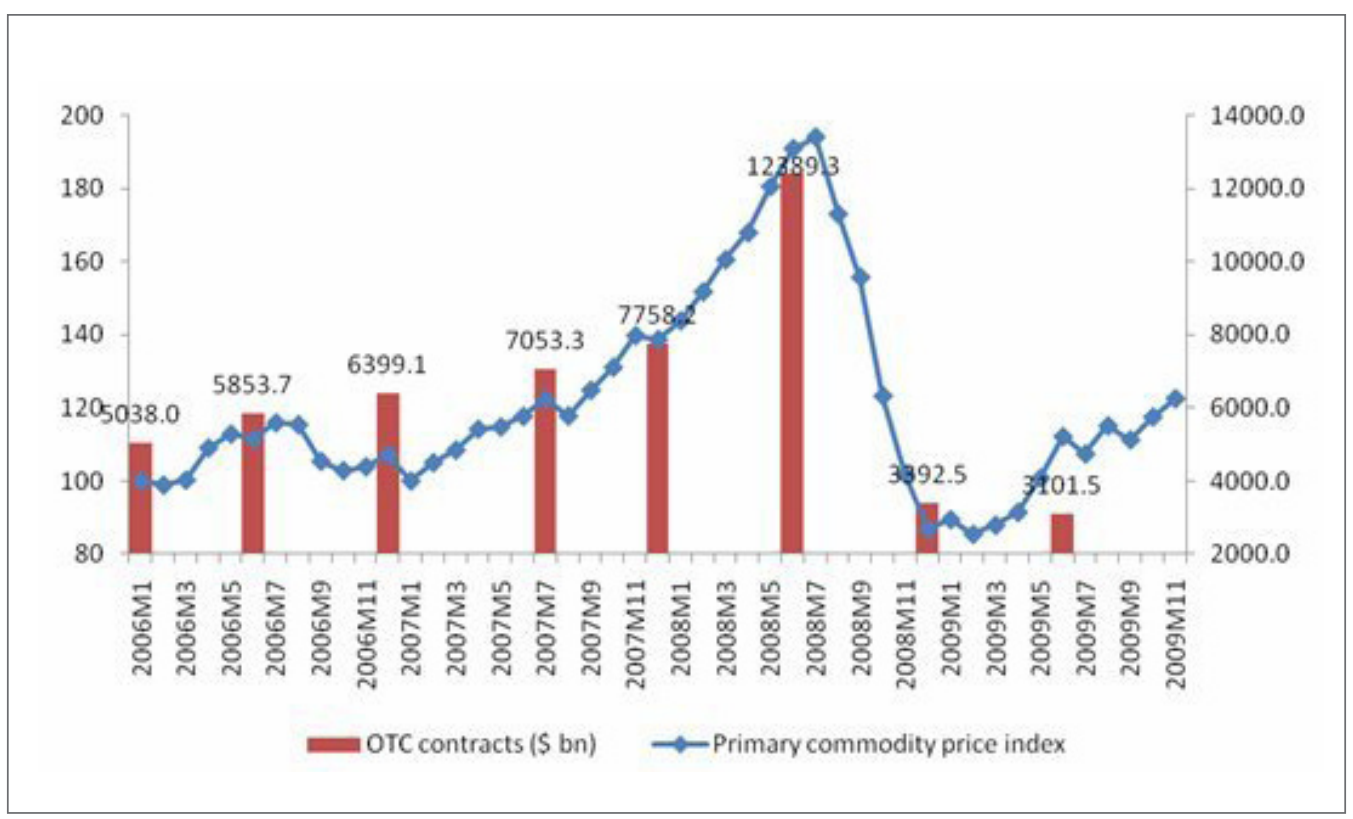

Source: Masters Capital Management

Figure 8. Percentage price change in selected commodity markets between 2001-2008

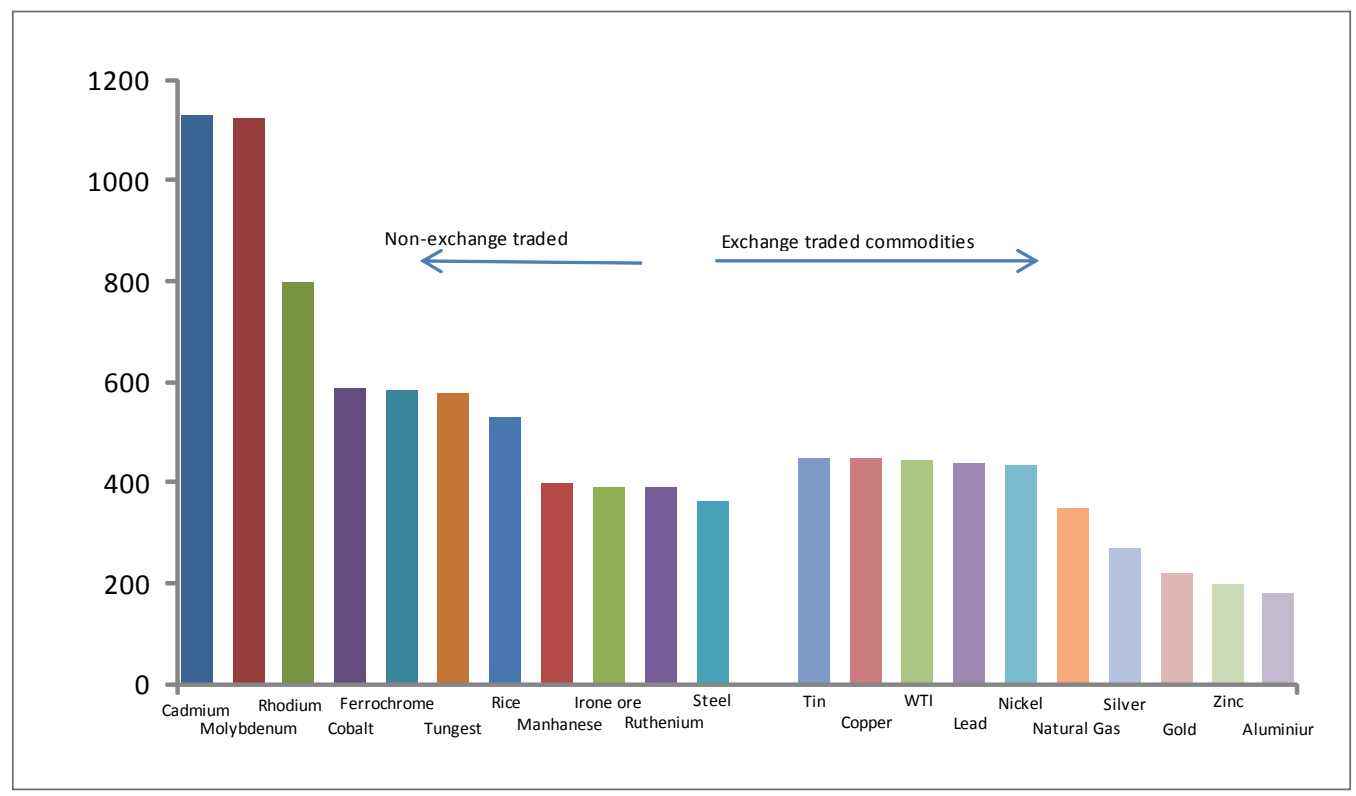

Source: Central Bank of Argentina, Financialization of Commodity Markets: Nonlinear Consequences from Heterogeneous Agent Behaviour, Working Paper 2009/44, based on the reproduced data from Deuthsche Bank, Commodities and the Role of Speculation, 2008 
Figure 9. Percentage price change in selected commodity markets between 2007-2008

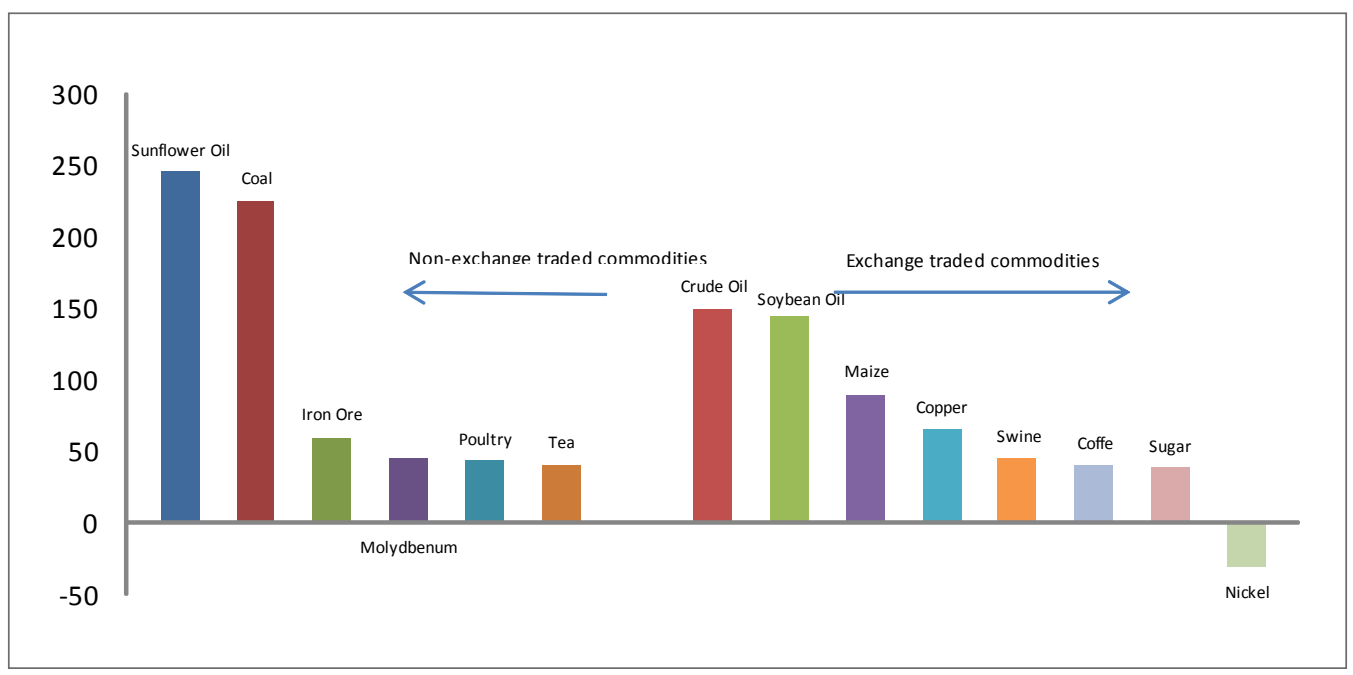

Source: Central Bank of Argentina, Financialization of Commodity Markets: Nonlinear Consequences from Heterogeneous Agent Behaviour, Working Paper 2009/44, based on the reproduced data from J. Vinals, Commodity Prices, Inflation and Monetary Policy, 2008

Table 1. Change in Commodity Prices, January 3, 2006 - April 15, 2008

\begin{tabular}{|l|l|l|l|}
\hline Commodity & January 2006 & April 2008 & Change \\
\hline Panel A. Futures Markets Included in Popular Indexes & & & \\
\hline Corn & & & \\
\hline Soybeans & $\$ 2,20 / \mathrm{bu}$. & $\$ 6,06 / \mathrm{bu}$. & $175 \%$ \\
\hline Soybeans Oil & $\$ 6,28 / \mathrm{bu}$. & $\$ 13,80 / \mathrm{bu}$. & $120 \%$ \\
\hline CBOT Wheat & $22,96 \mathrm{c} / \mathrm{lb}$. & $62,52 \mathrm{c} / \mathrm{lb}$. & $172 \%$ \\
\hline KCBOT Wheat & $\$ 3,46 / \mathrm{bu}$. & $\$ 8,96 / \mathrm{bu}$. & $159 \%$ \\
\hline Cotton & $\$ 3,90 / \mathrm{bu}$. & $\$ 9,50 / \mathrm{bu}$. & $136 \%$ \\
\hline Live Cattle & $55,24 \mathrm{l} / \mathrm{b}$. & $75,23 \mathrm{l} / \mathrm{b}$. & $36 \%$ \\
\hline Feeder Cattle & $\$ 96,37 / \mathrm{cwt}$. & $\$ 91,57 / \mathrm{cwt}$. & $-5 \%$ \\
\hline Lean Hogs & $\$ 114,00 / \mathrm{cwt}$. & $\$ 103,95 / \mathrm{cwt}$ & $-9 \%$ \\
\hline Panel B. Futures Markets not & $\$ 64,65 / \mathrm{cwt}$. & $\% 71,65 / \mathrm{cwt}$. & $11 \%$ \\
\hline Included in Popular Indexes & & & \\
\hline Rough Rice & & & \\
\hline Fluid Milk & $\$ 8,27 / \mathrm{lb}$. & $\$ 22,17 / \mathrm{lb}$. & $168 \%$ \\
\hline Panel C. No Futures Markets & $\$ 12,65 / \mathrm{cwt}$. & $\$ 17,29 / \mathrm{cwt}$. & $37 \%$ \\
\hline Apples Fresh Use & & & \\
\hline Edible Beans & $\$ 0,26 / \mathrm{lb}$. & $\$ 0,41 / / \mathrm{b}$. & $58 \%$ \\
\hline Source: & $\$ 19,30 / \mathrm{cwt}$. & $\$ 34,40 / \mathrm{cwt}$. & $78 \%$ \\
\hline
\end{tabular}

Source: Irwin, S.H., Sanders, D.R., Merrin, R.P., (2009). Devil or Angel? The Role of Speculation in the Recent Commodity Price Boom (and Bust), The American Journal of Agricultural Economics, August 2009

Notes: All prices refer to the relevant nearby futures price except apples and edible beans, which are monthly prices received by farmer 
Similar research highlighting this inconsistency was made basing on four examples of commodities over January 2006 and April 2008. Panels B and C in Table 1 present rough rice futures and fluid milk futures, not included in popular commodity indices tracked by index funds, and their respective rise of $162 \%$ and $37 \%$, over the analysed period. Apples for fresh use and edible beans also do not have futures markets and thus no index fund investment, yet prices in these markets increased $58 \%$ and $78 \%$, respectively, over the same time interval (Irwin, Sanders, Merrin, 2009). The question frequently asked by opponents of financial participant's blame was if speculation caused a price bubble in commodity prices, why then did prices increased substantially in commodity markets without any index fund activity?

The data provided does not draw a clear and precise line between exchange and non-exchange trade commodities in term of price valuation but it can be surely strong evidence in a debate of the real influence of financial markets on commodity prices.

\section{Potential impact of regulating com- modity derivatives markets}

Many argue that increased involvement of financial market players in commodities markets and potential profits they made resulted in increased food and oil prices which impacted the global economy and sparked the debate over the desire for speculative earnings at the expense of human hunger and the global economic slowdown.

Amid the lively debate on putting tighter restrictions on financial participants of commodity markets to prevent similar situation in the future there are still many concerns about the outcome of any regulations imposed by relevant authorities. Many argue that any limits are likely to have a significant affect on the commodity derivatives market and products used by companies for risk management purposes (Vito, 2011).

As there is still no clear evidence indicating the positive effects of regulatory actions, there are some concerns about the impact of any undertaken actions, for instance:

- restrictions can increase market risk because customized commodity derivatives would become less available,

- regulator's vague language can increase market risk because end users may elect to hedge their risk less frequently due to legal uncertainties,

- proposals could increase market risk because end users would hedge less due to increased costs related to capital and margin requirements,

- higher costs and less certainty around hedging activity can lead to higher prices and greater price volatility in commodity markets,

- established position limits coupled with restricting hedge exemptions may harm the commodity market in general (International Swaps and Derivatives Association, 2009).

The public disclosure of harmonised position information would evidently require the scope of derivatives reported to be transposed into their various underlying factor risks, including the counterparty risk inherent in each bilateral trade (Wholesale Market Brokers' Association, London Energy Brokers' Association, 2011). This could eventually lead to a necessity to analyse and disclose each commodities transaction separately. Even now many market participants argue that the huge amount of data generated by those obligations could not be used effectively. To be of any utility, this data would need to be global in scope to capture the systemic provenance of all traded commodities and participants (Financial Services Authority, HM Treasury, 2009). Some opinions highlight that the sheer scope and size of such an undertaking for little or no public gain would be difficult to gauge positively in the context of any impact or risk-reward analysis.

Additionally, market participants often note that all OTC products should be treated equally, whether cash deals, forwards, financially settled derivatives or physically settled derivatives. Within this level playing field of scope and regulation, the market should decide how best, and most efficiently, to organise its business with respect to price formation and risk transfer.

\section{Final Conclusions}

It is clear that the rapid growth of index investments in commodity markets revealed the process of "financialization" of commodities, (which made commodities in some way more correlated with each other and the overall situation on financial markets). However there is still little data indicating that it was the speculation, rather than fundamentals, which caused commodity prices to rise. It seems possible nonetheless, that finan- 

14. Garman, T., Forgue, R., (2010). Personal finance, South-Western Cengage Learning.

15. Gilbert, C.L., (2009). Commodity Speculation and Commodity Investments, Journal of Commodity Markets and Risk Managements.

16. Gorton, G., Rouwenhorst. K.G., (2006), Facts and fantasies about commodity futures, Financial Analysts Journal 62 (2), March/April 2006.

17. Hamilton, J.D., (2008). Understanding Crude Oil Prices. Working Paper, Department of Economics, University of California-San Diego.

18. Hieronymus, T.A., (1977). Economics of Futures Trading for Commercial and Personal Profit, New York, Commodity Research Bureau 1977.

19. HM Treasury, (2009). Role of speculation in driving the oil price.

20. Horcher, A.K., (2005). Essentials of Financial Risk Management, New Jersey: Wiley \& Sons, Inc.

21. Hughes J. (2006) Investor interest spurs new commodity indices, Financial Times.

22. International Swaps and Derivatives Association, (2009). Impact of Treasury's OTC Derivatives Legislation on Commodity Derivatives, October 2009.

23. Irwin, S.H., Sanders, D.R., Merrin, R.P., (2009). Devil or Angel? The Role of Speculation in the Recent Commodity Price Boom (and Bust), The American Journal of Agricultural Economics, August 2009.

24. Kevin S. (2011) Commodity And Financial Derivatives, Prentice Hall Of India.

25. Kilian, L., (2009). Not all oil price shocks are alike: Disentangling demand and supply shocks in the crude oil market, American Economic Review, 99 (3), June 2009.

26. Knoepfel I. (2011) Responsible investment in commodities, onValues Investment Strategies and Research.

27. Kyle, A., Xiong, W., (2001). Contagion as a wealth effect, Journal of Finance, 56 (4).

28. Masters, M.W., White, A.K. (2008) The Accidental Hunt Brothers: How Institutional Investors are Driving up Food and Energy Prices.

29. Mittal, A., (2009) The 2008 Food Price Crisis: Rethinking Food Security Policies,

G-24 Discussion Paper Series.

30. Tang, K., Xiong, W., (2011). Index Investment and Financialization of Commodities, Princeton University.
31. The Economist Magazine, Crisis prevention, vol. 09/2011.

32. The Times of India (2011). Strong dollar pummels commodities, May 7, 2011.

33. Trostle, R., (2008). Global Agricultural Supply and Demand: Factors Contributing to the Recent Increase in Food Prices, Economic Research Service Report from United States Department of Agriculture.

34. Turner, A., Justham, A., Farrimond, J., Hill, J., (2011) The oil market, Financial Supervisory Authority Paper.

35. U.S. Commodity Futures Trading Commission, (2011). Available at: http://www.cftc.gov/index. htm.

36. Vito, B., (2011). Revisiting the inadvertent investment company, Fordham Journal of Corporate \& Financial Law.

37. Wholesale Market Brokers' Association, London Energy Brokers' Association, (2011). Response to European Commission on MiFID2 Consultation.

\section{Notes}

1 The Morgan Stanley Commodity Related Equity Index is based on shares of widely held companies involved in commodity-related industries such as energy (e.g. oil and gas production and oilfield services and equipment), non-ferrous metals, precious metals, agriculture and forest products.

2 The DJ-UBSCI Energy Sub-Index index is composed of futures contracts on crude oil, heating oil, unleaded gasoline and natural gas and reflects the return of underlying commodity futures price movements only. It is quoted in USD

3 The Thomson Reuters/Jefferies CRB index is comprised of 19 commodities: Aluminium, Cocoa, Coffee, Copper, Corn, Cotton, Crude Oil, Gold, Heating Oil, Lean Hogs, Live Cattle, Natural Gas, Nickel, Orange Juice, Silver, Soybeans, Sugar, Unleaded Gas and Wheat.

\section{Acknowledgements}

I would like to thank Gary Roberts, Katie Fisher, Richard Caine and Mr Piotr Wiśniewski for their useful comments and remarks during preparations and discussions on the paper 
